\title{
明治期家屋台帳による大磯の初期別荘建築の実態 近代大磯における別荘建築に関する研究 \\ CONSIDERING THE CONSTRUCTION OF VACATION VILLAS IN OISO THROUGH MEIJI PERIOD HOUSING REGISTRIES
}

Research into the construction of vacation villass in modern OISO

\author{
水沼淑子* \\ Yoshiko MIZUNUMA
}

\begin{abstract}
This paper aims to examine to consider the construction of vacation villas in Oiso through "Oiso Town Hall Administrative Documents". The location, size of the land, arrangement of buildings, size of the main building, and layout of rooms were analyzed for 71 villas recorded in turn of the century housing registries, which were located in a broad area from central to outer Oiso. There were villas exceeding 3,300 square meters, while others were less than 330 square meters. Multiple buildings were constructed in many cases, including only two villas that had Western-style houses for visitors. Some large-scale villas had thatched roofs, which was a reflection of rural architecture. The size of the main buildings in some cases exceeded 330 square meters, but almost villas were small to medium-sized buildings. The installation of bathing facilities, which were sometimes in separate bathhouses or in other cases protruding out from other buildings, suggests their great importance at these seaside villas.
\end{abstract}

\section{Keywords : Oiso, Meiji Period, Villas, Housing Registries.}

大磯，明治期，別荘，家屋台帳

\section{1. はじめに}

大磯町は明治 18(1885)年の海水浴場開設、明治 20(1887)年の鉄 道駅設置などを契機に別荘地として発展した。戦前期、大磯のみで なく湘南一帯は別荘地として発展したが、関東大震災による被害や 昭和戦後期の開発により明治期に遡る別荘建築の遺構はほぼ確認で きず、明治期の別荘建築の様相を知る手がかりは極めて乏しい。

大磯における明治期の別荘建築の実態については、大磯町文化財 調查報告書第 37 集 大磯のすまい(1)』1)（以下『大磯のすまい』） 『大磯町史 7 通史編 近現代』2) や『なつかしの風景 II 家と町 並み 大磯町郷土資料館企画展図録』3) などに断片的に紹介されて いるものの、所有者、立地、規模、平面、意匠などについての詳細 な検討はいまだ充分とはいえない。

ところで、大磯の別荘建築の様相を知る資料として、大磯町が所 蔵寸る「旧大磯町役場資料」4）があり、既にその一部が前掲の『大 磯のすまい』に報告されている。すなわち、松本順や岩崎久弥など 11 件の別荘に関寸る「家屋位置図及方位」図と、同書巻末に付され た「大磯町別荘建築所在リスト」である。「大磯町別荘建築所在リス 卜」は、所有者名、所在地、所有者住所、入居年代、転出年代、現 況、建築年代、主屋構造形式を地番順に記載する。記載内容の根拠 については明記されないものの、同書凡例に「別荘建築各戸調查報 告の見出しの内、台帳の項目」資料として挙げられた「『建物台帳』 (明治 27 年)、『家屋台帳』(明治 32 年以前)」から作成されたものと
考えられる。これらは「旧大磯町役場資料」の一部であり、前者は 「明治廿七年一月改正建物台帳」と表題をもつ資料、後者は表題、 年紀ともに欠くものの、資料整理上は「家屋台帳」と呼ばれている 資料である。

旧大磯町役場資料のうち家屋に関連する文書（以下「家屋関連行 政文書」とする）は、従来知られていた先の台帳形式のもののみで なく、家屋の新築、取崩などに関する届出形式の文書が、明治 29(1896)年 1 月から昭和 15(1940)年 12 月までほぼ連続して確認で きることが判明した。

本研究は、まず、大磯町所蔵家屋関連行政文書の概要を明らかに し、次いで同文書を用い、明治 30 年代初頭、すなわち大磯におけ る初期の別荘建築の様相について詳細に検討しようとするものであ る5)。

\section{2. 大磯町所蔵家屋関連行政文書}

大磯町所蔵家屋関連行政文書には、『大磯の寸まい』にも掲載さ れた「家屋台帳」など台帳形式の文書と、「建物ニ関スル書類」「家 屋届書経」などの表題をもつ家屋新築や取壊に関連する届出を経じ た文書（以下「家屋届」とする）が確認できる（表 1)。

台帳形式の家屋関連行政文書は少なくとも 3 種確認でき、先に述 べた「明治廿七年一月改正建物台帳」と表題をもつ台帳（以下「 27 年建物台帳」)、表題、年紀ともに欠くものの、備考欄記載事項の日 


\section{表 1 大磯町所蔵家屋関連行政文書}

\begin{tabular}{|c|c|c|c|c|c|}
\hline \multirow{4}{*}{ 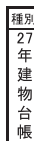 } & 番号 & 開始 & 終了 & 性数 & \begin{tabular}{|r|r|} 
表题 \\
\end{tabular} \\
\hline & 1 & 明治26年11月30日 & 明治 29 年 9 月 25 日 & 403 & \begin{tabular}{|l|l} 
明治廿七年一月改正建物台帳 \\
\end{tabular} \\
\hline & 2 & 明治 25 年9月24日 & 明治30年6月 3 日 & 307 & 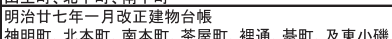 \\
\hline & 3 & 明治 25 年 3 月 20 日 & 明治30年6月 3 日 & 424 & 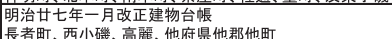 \\
\hline 30 & 1 & 不明 & & - & $\begin{array}{l}\text { (表題なL) } \\
\text { (a) }\end{array}$ \\
\hline 年 & 2 & 旦付なし & & 139 & (表題なし) \\
\hline & 3 & 日付なし(但明治30年11月 & 月19日記事記馢あり) & 151 & （表題なし） \\
\hline & 4 & 日付なし & & 170 & (表題なし) \\
\hline 帳 & 5 & 日付な（但明治32年 3 月 & 28日取崩序出反映) & 91 & (表題なし) \\
\hline 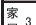 & 1 & 明治38年10月4日 & 大正8年2月26日 & & (表題なし) \\
\hline & 2 & 明治37年4月15日 & 明治45年4月8日 & 49 & (表題なし) \\
\hline 䀼年 & 3 & 明治 37 年11月5日 & 大正 4 年 3 月 9 日 & 212 & 大正四年三月調查 家屋取崩綴 \\
\hline & 1 & 明治29年1月17日 & 明治 30 年 12 月 $23 \mathrm{E}$ & 127 & 明治二拾九年四月八日起建物䫄届書類 \\
\hline & 2 & 明治31年1月12日 & 明治 36 年1月26日 & 311 & 明治三十一年一月起 建物二関スル書類 \\
\hline & 3 & 明治37年4月 & 明治40年12月 & 442 & 明治三十七年度起 建物二関スル書類 \\
\hline & 4 & 明治 41 年1月10日 & 明治 42 年 12 月 28 & 315 & 明治四十一年一月 家屋二関スル書類 \\
\hline & 5 & 明治43年1月13日 & 明治 43 年 12 月 $27 \mathrm{E}$ & 192 & (表題なし) \\
\hline & 6 & 明治44年4月7日 & 明治 44 年 12 月 $28 \mathrm{E}$ & 78 & 明治四十四年分～建物諸書類綴 \\
\hline & 7 & 明治44年12月21日 & 大正元年12月26日 & 191 & 明治四十五年一月与利 建物書類綴 \\
\hline & 8 & 大正2年1月8日 & 大正2年12月23日 & 178 & 大正二年度 建物書類綴 \\
\hline & 9 & 大正3年1月8日 & 大正 3 年 12 月 25 日 & & 大正参年度 建物書類綴 \\
\hline & 10 & 大正4年1月9日 & 大正5年3月30日 & 256 & 大正四年度 建物書類綴 \\
\hline & 11 & 大正6年4月11日 & 大正7年3月30日 & 380 & 大正六年度 建物届書類綴 \\
\hline & 12 & 大正7年4月17日 & 大正 8 年 3 月 31 日 & 225 & 大正七年壹月起 家屋届書綴 \\
\hline & 13 & 大正8年4月1日 & 大正 9 年3月31日 & 241 & 大正八年 家屋届書綴 \\
\hline & 14 & 大正9年4月1日 & 大正10年4月3日 & 175 & 大正九年分 家屋関係書類憡 \\
\hline & 15 & 大正10年4月7日 & 大正11年4月19日 & 244 & 大正拾年分 家屋書類 \\
\hline & 16 & 大正11年4月2日 & 大正12年3月20日 & & 大正十一年度 税務書類 家屋届書 \\
\hline 家 & 17 & 大正12年10月1日 & 大正14年9月 & 90 & (表題なし) \\
\hline 屋 & 18 & 大正12年9月 & 大正15年3月 & 204 & 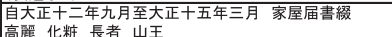 \\
\hline & 19 & 大正12年9月 & 大正15年3月 & 180 & $\begin{array}{l}\text { 自大正十二脌九月室大正十五年三月 家屋届書緅 } \\
\text { 神明 北本南本屋 }\end{array}$ \\
\hline & 20 & 大正12年9月 & 大正15年3月 & 305 & $\begin{array}{l}\text { 自大正十二年九月至大正十五年三月 } \\
\text { 家屋届畫纉 }\end{array}$ \\
\hline & 21 & 大正12年9月 & 大正15年3月 & 161 & 自大正十二年九月至 十五年三月 家屋届書綴 \\
\hline & 22 & 大正15年3月31日 & 昭和2年3月11日 & 187 & 大正十五年度 家屋届書綴 \\
\hline & 23 & 昭和2年3月30日 & 昭和3 年4月25日 & 361 & (表題なし) \\
\hline & 24 & 昭和4年2月4日 & 昭和5 年3月 31 日 & 573 & (表題なし) \\
\hline & 25 & 昭和5年4月1日 & 昭和 6 年 3 月 31 日 & 137 & (表題なし) \\
\hline & 26 & 昭和6年4月1日 & 昭和7年3月31日 & & (表題なし) \\
\hline & 27 & 昭和7年4月 & 昭和7年9月 & & (表題なし) \\
\hline & 28 & 昭和7年5月16日 & 昭和 8 年 3 月 29 日 & 67 & 家屋届書綴 \\
\hline & 29 & 昭和9年4月4日 & 昭和11年3月31日 & 356 & 昭和九年度分 昭和十年度分 家屋届書緅 \\
\hline & 30 & 昭和12年4月5日 & 昭和14年3月24日 & 333 & 昭和十二年 縣税雑種税臺帳 \\
\hline & 31 & 昭和13年12月20日 & 昭和15年12月16 & 117 & (表題なし) \\
\hline & & 昭和14年12月14日 & 昭和15年12月 16 & & 昭和十五年 \\
\hline
\end{tabular}

付から明治 30 年代初頭に作成されたと考えられる台帳（以下「30 年家屋台帳」）6)、さらに、「30 年家屋台帳」と類似した形式である ものの、同様に備考欄記載事項の日付から明治 37(1904)年以降に作 成されたと考えられる台帳 (以下「37 年家屋台帳」) 7)が確認できる。

$\lceil 27$ 年建物台帳」は 3 冊確認でき、いずれの台帳表紙にも「明治 廿七年一月改正建物台帳」と表題があり、左上にはそれぞれ、「山王 町 北下町 南下町」、「神明町 北本町 南本町 茶屋町 裡通 基町 及 東小磯」「長者町 西小磯 高麗 他府県他郡市他町」と 記載される。「27 年建物台帳」の記載事項は、家主、地主、所在地、 敷地規模、建物構造規模数量、届出年月日を基本とするが、いずれ
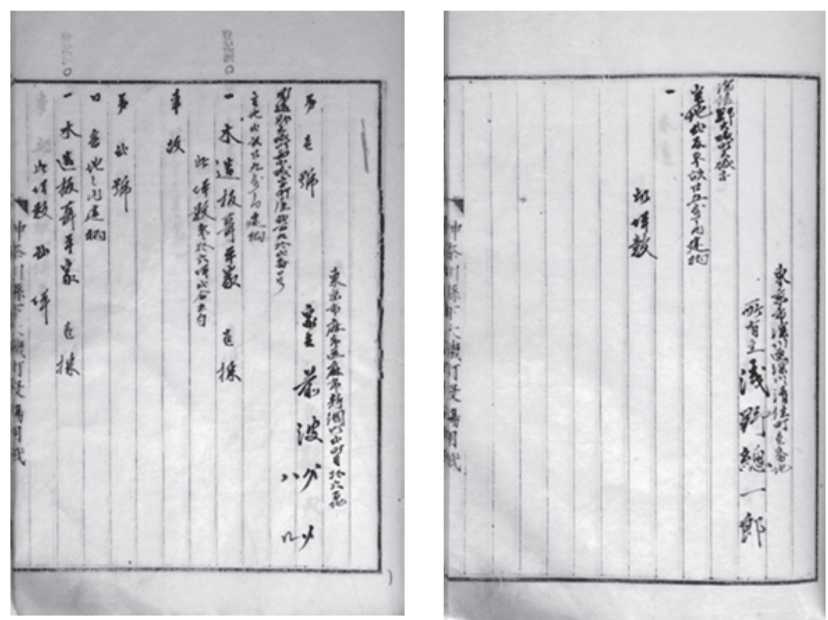

図 127 年別荘等建物台帳記載例
かの記載がない届出もある。「神奈川県下大磯町役場用箋」と印刷さ れた縦䍔のある用紙に筆書きされ、欄外への「登記済」朱書き、事 故欄への朱書き日付、担当者捺印などが確認できる台帳もある。「他 府県他郡市他町」の建物台帳に記載されるのは、住所を大磯町以外 に置く所有者の建物を記載した台帳で、記載件数は 117 件あり、字 順に綴じられている部分もあるものの記載順に一定のルールは見い だせない。記載された建物所有者の多くは大磯に別荘を有していた ことが知られる人物であることから、ここでは、当該台帳を「 27 年 別荘等建物台帳」と呼ぶことにする。もつとも日付の遡る届出は吾 妻村西山金三郎の明治 24 (1891) 年 3 月の届出で、山㠃五郎吉の明治 30 (1897) 年 6 月 23 日付け届出まで一諸に綴じられている。図 1 に一 例を挙げるが、前波クメ（ハル） ${ }^{8)}$ の台帳（図 1 左）は建物規模、 構造、屋根仕上げなど詳細に記載するも、浅野総一郎の台帳（図 1 右）には所在地以外記載されないなど統一を欠く。

「30 年家屋台帳」は 5 冊確認できる。いずれも表紙を持たず作成 年も明記されない。1 冊は虫喰いによって大きく破損しており、一 部判読可能な部分から高麗、山王後に所在する家屋の台帳を含む簿 冊であることが判明する。3 冊は罢紙様の薄紙を表紙にし、次ペー ジから家屋台帳を綴じる形式の簿冊で、北本町、南本町で 1 冊、茶 屋町、台町で 1 冊、東柳原、西柳原などで 1 冊の簿冊とする。残り の 1 冊は、形式は他の 3 冊と全く同じだが、表紙に氏名一覽を付し た簿冊で、一覧には岩崎彌之助、山縣有朋など 81 名が記載される。 さらに、西小磯についても別途氏名一覧が作成され、伊藤博文、鍋 島直大など 10 名が記載される。当該台帳は、「27 年別荘等建物台帳」 と同様、他府県他郡市他町居住者所有家屋の台帳と考えられ、台帳 は一覧順に綴じられている。一覧に記載された氏名の多くはすでに 大磯における別荘所有者としてよく知られた人物を多く含むことか ら、当該台帳をここでは「30 年別荘等家屋台帳」と呼ぶことにする。

「30 年家屋台帳」は、1 件ごとに所在地、敷地規模、地主、家主、 を記し、建物は番号を付して「居宅」「蔵」などの家屋種別、「草莫」

「板莫」などの屋根仕上げ、建物規模を記載する (図 2 右)。建物規 模は、主体部分の規模と 2 階、玄関、廊下、浴室、内庇などの部位 別規模を分割して記載する形式をとる。また、一件ごとに「家屋位 置及方位」と題する図（以下「家屋図」）が付され、方位、建物番号、 建物形状、部位ごとの寸法、屋根仕上げなどが表記される(図 2 左)。
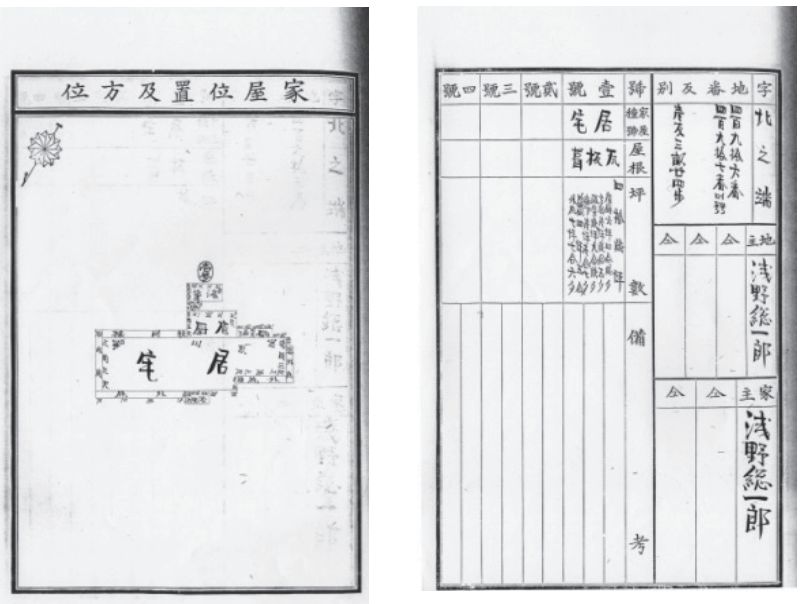

図 230 年別荘等家屋台帳記載例 
$\lceil 37$ 年家屋台帳」は 3 冊確認できる。 1 冊は「大正四年三月調査 家屋取崩綴」と表題があり、字別に台帳を綴じている。後半には「別 荘」と朱書きされた中表紙に続き徳川茂承や宮島善治郎などの台帳 が続く。台帳記載内容は「30 年家屋台帳」とほぼ同様だが、「家屋 位置及方位」図ではなく、「建物式分一間尺図」が付される。「建物 武分一間尺図」は、縦横買線の入った用箋に建物の略平面を描き、 畳、土間、押入床板間内縁などの部位ごとに着彩し間仕切りも記載 されるため「家屋図」に比して平面構成の詳細が判明する。いずれ の台帳も、建物備考闌に取崩年月日が朱書きされ、表題にあるよう に取崩した建物のみを綴った台帳であることがわかる。

もう一冊は、表紙、年紀ともに欠き、破損が著しく記載内容を確 認不能な台帳が多いものの、台帳の形式は「大正四年三月調查 家 屋取崩綴」と同一で、山王後や高麗などに所在する建物について記 載する。建物の備考欄には取崩や焼失などの朱書きが加筆され、こ の台帳も取崩した建物だけを綴じた台帳であることがわかる。

最後の 1 冊も、「大正四年三月調查 家屋取崩綴」と同一形式の 台帳で、表紙、年紀ともにないが、伊藤鉾太郎、森村市左エ門など 大磯外に居所を置く所有者の家屋台帳を綴じた台帳であり、上記 2 冊と同様、建物備考欄に取崩年月日が記載されることから、取崩し た建物の台帳のみを綴じていることがわかる。図 3 は図 2 の浅野総 一郎所有建物が大正 4(1915) 年 9 月 30 日に焼失したことを届け出た ものであり、建物形状は図 2 左の「家屋図」と良く合致し、間取の 様相が判明する。

以上のように、現時点で確認できる「37 年家屋台帳」は、字別に 作成された元台帳から取崩した建物のみを取り出しまとめたものと 考えられ、「30 年家屋台帳」のように大磯に所在する建物を網羅的 に記載した台帳ではないことがわかる。

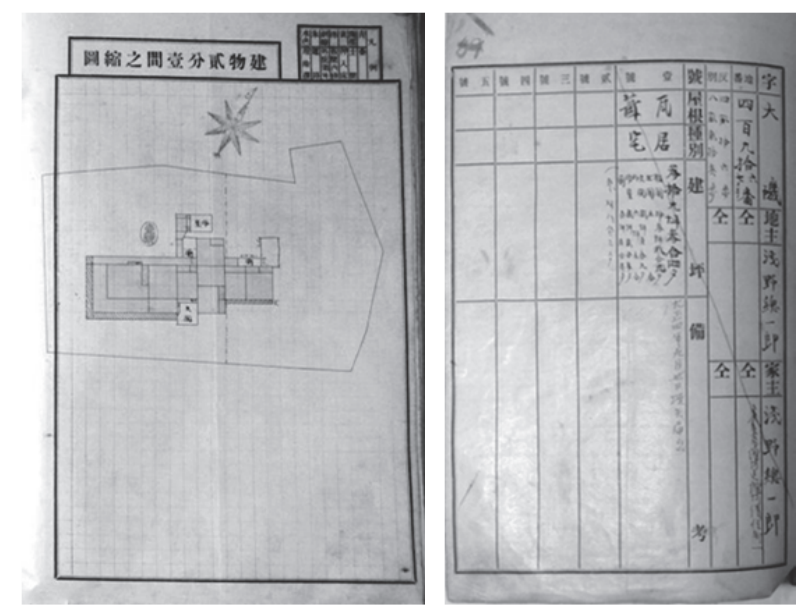

図 337 年家屋台帳記載例

次に「家屋届」は、家屋の新築、増改築、取崩し、売買、相続、 名義変更などを含み、各届出の記載内容は、届出種別、申請者氏名 住所、申請建物位置、敷地規模、建物種類、建物規模、届出年月日 などからなる。一定の形式はなく、申請者によって形式は異なる。 新築届の場合、詳細な平面図が添付される場合もあるものの、建物 形状のみを示寸図面であったり、図面が添付されないこともある。 明治 29 (1896) 年 1 月から同 30 (1897) 年 12 月までの届を綴った「明 治二十九年四月起建物願届書類」から昭和 14 (1939) 年 12 月から同
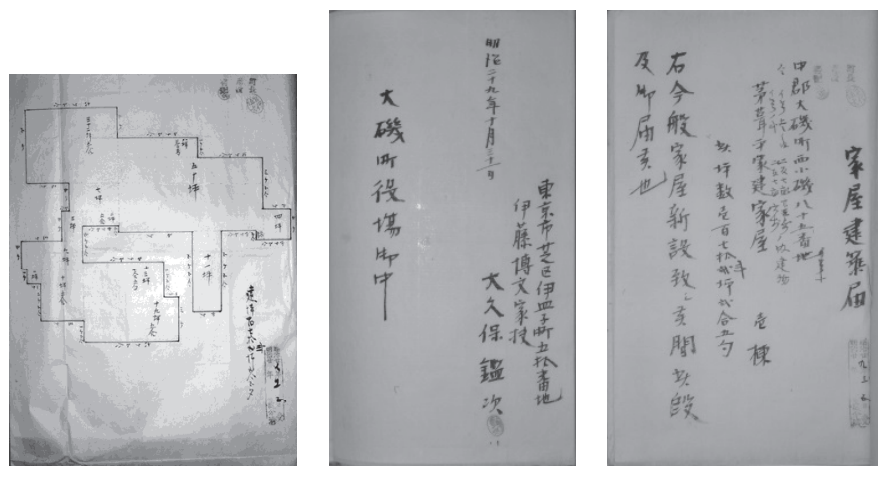

図 4 家屋届記載例

15 (1940) 年 12 月までの届を綴った「昭和十五年度 家屋届綴」まで、 途中 5 ケ年分を欠くものの、32 冊の「家屋届」が確認できる ${ }^{9)}$ 。

図 4 は「明治二十九年四月八日起建物願届書類」中に綴られた、 伊藤博文家扶大久保鑑次が届け出た明治 $29(1896)$ 年 10 月 31 日付 「家屋建築届」で、届出建物の所在地、敷地規模、届出建物の屋根 仕上げ、棟数、規模を記した文書部分と建物の外形図から成る。建 物の外形図は「30 年別荘等家屋台帳」記載の和館部分 (図 8) と合致 する。当該地に建つ建物の変遷については、伊藤博文逝去後の明治 43 (1910) 年 2 月 14 日、伊藤博邦が居宅や西洋館など 9 棟の「建物相 続届」を届け出ており、明治 29 (1896) 年以降建物が増設された可能 性を示唆する ${ }^{10)}$ 。

以上のように、台帳形式の文書が当該時期におけるストックとし ての家屋の状態を示すものとすれば、「家屋届」は大磯における家屋 の時系列での変容を追跡することができる資料であり、大磯におけ る別荘建築の様相の一端を明らかにしうる貴重な資料である。これ ら台帳形式の資料と届出形式の資料双方を用いることにより、大磯 における別荘建築の詳細な様相を明らかにすることが可能である。

また、台帳形式の文書は 3 種あるものの、「30 年家屋台帳」は、 一部地域の台帳を欠くものの、大磯内に所在する家屋を網羅的に台 帳化した資料であり、敷地内に所在する各建物の規模、屋根仕上げ、 建物形状などを知ることができる貴重な資料である。

\section{3.「30 年別荘等家屋台帳」にみる初期別荘の様相}

大磯における別荘建築の様相を明らかにする端緒として「30 年別 荘等家屋台帳」記載の別荘について検討する。明治期の大磯の別荘 建築については、関東大震災やその後の開発でほとんど失われてお り、その様相を明らかにすることは重要と考えられる。

$「 30$ 年別荘等家屋台帳」は、先行寸る「27 年別荘等建物台帳」 11) と比較すると、主屋規模、構造形式など合致する点が多いものの、 同一敷地内の建物数は「30 年別荘等家屋台帳」の方が総じて多く記 載されている。こうした差異は、「 27 年別荘等建物台帳」が届出に 基づき作成されたと考えられるのに比して、「30 年別荘等家屋台帳」 は網羅的な調查に基づき作成されたことを窥わせる。「30 年家屋台 帳」の事項記載欄、「家屋図」は筆跡から判断し、同一人物が作成し たと考えられ、このことも一定時期に調査に基づき作成された台帳 であることを裏付ける。

「30 年別荘等家屋台帳」に記載された 91 件は、同一人物所有家 屋であっても地番が異なる場合等別台帳が作成され、家主岩崎彌之 
表 230 年別荘等家屋台帳記載別荘一覧

\begin{tabular}{|c|c|c|c|c|c|c|c|c|c|c|c|c|}
\hline & \multirow[b]{2}{*}{ 字 } & \multirow[b]{2}{*}{ 筆頭地番 } & \multirow[b]{2}{*}{$\begin{array}{l}\text { 台帳 } \\
\text { 番号 }\end{array}$} & \multirow[b]{2}{*}{ 家主 } & \multicolumn{4}{|c|}{ 主屋 } & \multicolumn{2}{|c|}{ 敷地 } & 主屋内 & \\
\hline & & & & & 家屋種別 & 屋根仕上 & $\mid \begin{array}{l}\text { 階 } \\
\text { 数 }\end{array}$ & 延面積 (坪) & $\begin{array}{l}\text { 敷地面積 } \\
\text { (坪 }\end{array}$ & 地主 & $\begin{array}{l}\text { 溶室 } \\
\text { 規模 }\end{array}$ & 主屋以外の建物及規模(坪) \\
\hline & & 495 & 22 & 浅野総一郎 & 居宅 & 板葺 & 1 & 15.00 & 203 & 同 & - & \\
\hline & 北之端 & 496 & 21 & 浅野総一郎 & 居宅 & 望板莫 & 1 & 66.02 & 414 & 同 & 2.92 & \\
\hline & & 718 & 20 & 森村市太郎 & 居宅 & 丽葺 & 1 & 38.50 & 233 & 同 & 3.00 & \\
\hline & & 722 & 48 & $\begin{array}{l}\text { 森村豊 } \rightarrow \\
\text { 森村勇 }\end{array}$ & 居宅 & 瓦葷 & 2 & 50.00 & 323 & 同 & 2.00 & \\
\hline & & $7271^{* 1}$ & 15 & 酒井忠道 & 居宅 & 瓦菫 & 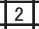 & 58.67 & $475^{* 2}$ & 同 & - & 居宅10.75/居宅30.50 \\
\hline & 䈴田 & 76511 & 17 & 三嶋彌太郎 & 居宅 & 瓦葺 & 2 & 94.47 & 151 & 同 & 3.00 & \\
\hline & & 786 & 18 & 三嶋彌太郎 & 居宅 & 板萓 & 1 & 10.00 & 127 & 同 & - & \\
\hline & & $769^{* 3}$ & 27 & \begin{tabular}{|l|} 
有村國彦 $\rightarrow$ \\
高島䨣之助
\end{tabular} & 居宅 & 瓦葺 & 1 & 44.45 & 534 & 同 & 3.25 & 居宅42.83/物置0.83/厠0.50 \\
\hline & & $773^{* 4}$ & 28 & 有村國彦 & 居宅 & 瓦莫 & 1 & 28.25 & $312^{* 5}$ & 同 & 2.25 & \\
\hline & & $839 * 6$ & 26 & 園田實德 & 居宅 & 瓦葺 & 2 & 54.13 & $264^{* 7}$ & 同 & - & 物置 1.0 /咸 0.50 \\
\hline & & $852^{* 8}$ & 16 & 渡辺治右工門 & 居宅 & 草葷 & 1 & 34.24 & $171^{* 9}$ & 同 & 4.00 & 居宅20.80/居宅5.25/居宅7.00 \\
\hline & 坂田山 & $870^{* 10}$ & 61 & 間宮作次郎 & 居宅 & 瓦革 & 1 & 24.00 & $213^{* 11}$ & 同 & - & 屓 0.50 \\
\hline & 付㟧 & & 62 & 間宮作次郎 & 居宅 & 板葺 & 1 & 19.50 & - & 同 & - & \\
\hline & T & $885^{* 12}$ & 42 & 片岡七郎 & 居宅 & 㼘革 & 1 & 20.00 & $122 * 13$ & 同 & 1.00 & \\
\hline & & 895 㐰 & 19 & 高木兼寛 & 居宅 & 亙莫 & 2 & 76.00 & 382 & 同 & 1.50 & 居宅 9.50 /夙 0.50 \\
\hline & & 895 & 35 & 石川満寿 & 居宅 & 亙莫 & 1 & 38.83 & 152 & 他 & - & 居宅及浴室5.50/居宅5.50 \\
\hline & & $918 \mathrm{a}$ & 25 & 砂葉順通 & 居宅 & 瓦莫 & 2 & 62.75 & 76 & 同 & - & 居宅7.00/物置及釜屋 3.83 \\
\hline & 神明町 & 941 & 58 & \begin{tabular}{|l} 
嶌暗登久 $\rightarrow$ \\
阿藤重兵衛
\end{tabular} & 居宅 & 瓦葺 & 1 & 16.00 & 152 & 同 & - & 居宅16.75 \\
\hline & & 9431 & 53 & 得能通要 & 居宅 & 板瓦茜 & 1 & 30.33 & 304 & 同 & 1.50 & 居宅及物置7.75 \\
\hline & 北本町 & $100711^{* 14}$ & 8 & 島津忠亮 & 居宅 & 瓦莫 & 1 & 98.96 & $240 * 15$ & 同 & 4.83 & $\begin{array}{l}\text { 居宅及土蔵 } 12.67 / \text { 居宅 } 12.75 \text { /物置及浴室 } 4.75 \text { /物置及植木室 } 7.00 / \text { 物置 } \\
0.89 \text { /咸 }\end{array}$ \\
\hline & & $1007 \square^{* 16}$ & 23 & 諫早家崇 & 居宅 & 瓦堇 & 1 & 50.13 & $362 * 17$ & 同 & 3.00 & \\
\hline$\underset{\text { 不坐 }}{大}$ & & 101011 & 38 & $\begin{array}{l}\text { 柿沼宇兵衛 } \rightarrow \\
\text { 梅浦精一 }\end{array}$ & 居宅 & 草葷 & 1 & 27.25 & 874 & 同 & 2.50 & \\
\hline & & 101111 & 39 & \begin{tabular}{|l|} 
柿沼宇兵衛 $\rightarrow$ \\
梅浦精一 \\
\end{tabular} & 居宅 & 草葷 & 2 & 31.25 & 289 & 同 & 3.75 & |物置2.25 \\
\hline & & $1013^{* 18}$ & 47 & 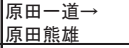 & 居宅 & 瓦莫 & 2 & 33.17 & $96^{* 19}$ & 同 & 1.50 & |物置1.50 \\
\hline & & 10141 & 70 & 栗野慎一郎 & 居宅 & 板葷 & 1 & 13.42 & 180 & 他 & - & \\
\hline & 南本町 & 1121 & 1 & 岩崎彌之助 & 居宅 & 草葷 & 2 & 205.11 & - & 同 & 19.52 & 居宅18.25/亜鉛造蔵15.00/屓1.00 \\
\hline & 他 & $\begin{array}{l}1143 \\
1243\end{array}$ & 2 & \begin{tabular}{|l|} 
岩崎久彌 $\rightarrow$ \\
岩崎彌之助
\end{tabular} & 居宅 & 草莫 & 1 & 164.14 & - & 同 & - & 居宅23.18/居宅15.00/写真暗室 0.56 /物置3.00/西洋料理場 5.25 \\
\hline & & 他*20 & 3 & 岩崎彌之助 & 居宅 & 瓦葷 & 1 & 38.33 & - & 同 & 3.00 & 物置 6.00 /唧筒置場 3.00 \\
\hline & & & 4 & 岩崎彌之助 & 居宅 & 瓦葺 & 1 & 23.25 & - & 同 & 1.00 & 居宅12.75/浴室1.00 \\
\hline & & & 5 & 岩崎彌之助 & 居宅 & 丽莫 & 1 & 38.58 & - & 同 & 1.00 & \\
\hline & & 1175 & 59 & 林保五郎 & 居宅 & 草板瓦莫 & 2 & 91.42 & 249 & 他 & 6.00 & 物置1.50 \\
\hline & & 11861 & 46 & 濱弘一 & 居宅 & 瓦莫 & 2 & 30.51 & 205 & 同 & 1.75 & \\
\hline & 台町 & 12481 & 10 & 小笠原長幹 & 居宅 & 瓦革 & 2 & 71.60 & 324 & 同 & - & 居宅14.50/居室6.50/茶室4.67/物置2.25/屓0.50 \\
\hline & & 1250 & 40 & $\mid \begin{array}{l}\text { 宮原玉 } \mathrm{E} \text { 平豊 } \\
\end{array}$ & 居宅 & 板瓦莫 & 2 & 36.55 & 178 & 同 & - & 浴室2.25/厠0.50 \\
\hline & & 1254 & 41 & \begin{tabular}{|l|} 
河野壽男 $\rightarrow$ \\
小林八郎
\end{tabular} & 居宅 & 瓦葷 & 1 & 44.11 & 178 & 同 & - & 居宅4.50/居宅8.00/居宅及物置7.00/浴室7.08 \\
\hline & 茶屋町 & 13141 & 9 & 樺山資紀 & 居宅 & 瓦葺 & 1 & 76.08 & - & 同 & - & 居宅7.67/居宅13.75/厠0.50 \\
\hline & & $13311 \square^{* 21}$ & 29 & 米倉一平 & 居宅 & 瓦惪 & 1 & 74.77 & $138^{* 22}$ & 同 & - & 居宅6.00 \\
\hline & 南浜岳 & $1943 * 23$ & 13 & 渡辺千秋 & 居宅 & 瓦葷 & 2 & 46.68 & - & 同 & - & \\
\hline & & 2038 & 24 & 加藤弘之 & 居宅 & 草瓦莫 & 2 & 51.70 & 330 & 同 & 3.38 & \\
\hline & 池田 & 2038 & 67 & 三井高保 & 居宅及浴室 & 草瓦板莫 & 2 & 204.57 & 1200 & 同 & 17.75 & 居宅20.25/居宅21.25/物置5.00/夙0.75 \\
\hline & 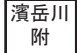 & $2279^{* 24}$ & 36 & \begin{tabular}{|l} 
後藤象二郎 $\rightarrow$ \\
开上竹次郎 \\
\end{tabular} & 居宅 & 草葷 & 1 & 59.67 & $1160^{* 25}$ & 同 & - & 居宅12.00/居宅12.00 \\
\hline & & & 37 & $\begin{array}{l}\text { 後藤象二郎 } \rightarrow \\
\text { 竹次郎 }\end{array}$ & 土蔵 & 瓦茸 & 1 & 21.00 & & 同 & - & \\
\hline & & $17 \square^{* 26}$ & 44 & 澤元衡 & 居宅 & 板草葺 & 1 & 20.25 & $66^{* 27}$ & 同 & - & 居宅物置9.25 \\
\hline & & $18^{* 28}$ & 49 & 藤田ぎん & 居宅 & 草葷 & 1 & 38.50 & $60^{* 29}$ & 同 & - & | 物置4.25 \\
\hline & 町厔 & $57^{* 30}$ & 54 & 松本順 & 居宅及土蔵 & 草板瓦葷 & 2 & 122.19 & - & 同 & 5.25 & 物置22.50 \\
\hline & & $57^{* 31}$ & 65 & 依田松呂 & 居宅 & 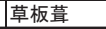 & 1 & 22.92 & $216^{* 32}$ & 同 & 3.25 & 物置2.00 \\
\hline & & $64^{* 33}$ & 64 & 張秀則 & 居宅 & 草莫 & 2 & 32.25 & $78^{* 34}$ & 同 & - & 釜屋浴室 3.33 /厠 0.50 \\
\hline & & $67^{* 35}$ & 33 & 柴山矢八 & 居宅 & 瓦革 & 1 & 29.50 & $593^{* 36}$ & 同 & - & 夙 1.83 \\
\hline & & $189^{* 37}$ & 45 & 田中茂 & 居宅 & 瓦荣 & 1 & 25.00 & $82 * 38$ & 同 & 2.00 & 厠 0.25 \\
\hline & |小淘綾 $\mid$ & $195^{* 39}$ & 7 & 山内豊景 & 居宅 & 瓦板荣 & 1 & 93.09 & $269^{* 40}$ & 同 & 2.50 & 居宅10.00 \\
\hline 東 & & 204 & 31 & 村田経芳 & 居宅 & 瓦葷 & 1 & 50.48 & 497 & 同 & - & 居宅11.29/居宅8.00/居宅 9.25 /物置6.50/物置0.50/物置3.00/薪部屋 0.83 \\
\hline 小 & & 200 & 32 & 村田経芳 & 居宅 & 草葷 & 1 & 17.11 & 287 & 同 & - & \\
\hline 磯 & & 224 & 34 & 本田親雄 & 居宅 & 瓦葺 & 1 & 29.92 & 76 & 同 & - & 物置及屓 1.00 \\
\hline & & 227 & 6 & 德川義禮 & 居宅 & 瓦葺 & 2 & 142.53 & 1163 & 同 & 7.50 & 土蔵及物入 10.00 /居宅 $10.00 /$ 物置及屓 8.00 \\
\hline & & 251 & 11 & 山縣有朋 & 居宅 & 瓦葷 & 2 & 70.58 & 492 & 同 & 6.50 & 居宅及物置25.00/厠0.50 \\
\hline & 海辺 & $273 * 41$ & 12 & 大隈重信 & 居宅及土蔵 & 草瓦莫 & 1 & 137.80 & - & 同 & 1.50 & 居宅 26.50 /居宅 5.25 / 物置 10.00 /浴室 3.38 / 物入 1.00 \\
\hline & & 280 & 14 & 陸奥宗光 & 居宅 & 草瓦莫 & 1 & 98.53 & 509 & 同 & 3.00 & 居宅5.25/物置3.50 \\
\hline & & 283 口 & 43 & 齊藤亀次郎 & 居宅 & 草板葺 & 1 & 35.92 & 170 & 同 & 3.75 & 居宅13.25 \\
\hline & 王城谷 & $361^{* 42}$ & 63 & 黒川彦兵衛 & 居宅物置浴室 & 瓦革 & 1 & 29.38 & $231^{* 43}$ & 同 & 3.00 & 厠 0.50 \\
\hline & 古屋敷 & 434 & 30 & 田中長兵衛 & 居宅及土蔵 & 草瓦莫 & 2 & 70.59 & 195 & 同 & 2.00 & 井戸屋2.25 \\
\hline & 宮上 & $1700^{* 44}$ & 69 & 佐藤重太郎 & 居宅 & 草葷 & 1 & 35.42 & $1022^{* 45}$ & 同 & - & 薪入場1.33 \\
\hline & 稲荷松 & 85 & 西1 & 伊藤博文 & 居宅 & 草葷 & 1 & 120.53 & 1649 & 同 & 10.00 & $\begin{array}{l}\text { 居宅54.50/西洋造居宅71.00/居宅20.09/物置浴室井戸 } 8.25 / \text { 居宅及馬車置 } \\
\text { 場 } 49.50 \text { /則0.25 }\end{array}$ \\
\hline & & $8514^{* 46}$ & 西2 & 鍋島直大 & 居宅 & 瓦葺 & 2 & 205.23 & $816^{* 47}$ & 同 & - & 居宅14.25/物置7.00 \\
\hline & 町屋 & $292 口^{* 48}$ & 西6 & 前波はる & 居宅 & 板葷 & 1 & 39.75 & $89^{* 49}$ & 同 & 2.25 & 居宅2.25/厠0.25 \\
\hline & & 408 & 西7 & 調所廣丈 & 居宅 & 板葷 & 1 & 23.75 & & 同 & - & 浴室3.75 \\
\hline 西 & & $422^{* 50}$ & 西5 & 伊藤巂吉 & 居宅 & 板葺 & 1 & 34.76 & $230^{* 51}$ & 同 & 5.00 & 居宅17.09/居宅8.50/厠0.25 \\
\hline 小 & & 418他*52 & 西3 & 上郎幸八 & 居宅 & 瓦莫 & 1 & 13.63 & & 他 & - & \\
\hline 磯 & & & 西4 & 上郎幸八 & 土蔵 & 瓦莫 & 2 & 12.00 & & 他 & - & \\
\hline & 切通 & & 西8 & 吉田茂 & 居宅 & 板葺 & 2 & 30.50 & & - & - & \\
\hline & & & 西9 & \begin{tabular}{|l|} 
上郎幸八 \\
吉田茂
\end{tabular} & 居宅 & 草葷 & 1 & 21.00 & & 同 & 1.50 & |居宅15.00/居宅浴室8.75/物置2.00 \\
\hline & & & 西10 & $\begin{array}{l}\text { 吉田茂 } \\
\text { 上郎幸八 }\end{array}$ & 西洋造居宅 & 亜鉛葷 & 2 & 39.25 & & 同 & - & \\
\hline
\end{tabular}

台帳に地番·敷地面積が記されていない場合、他資料から明らかにしイタリック体で示した。地番及び敷地面積特定の根拠を表1の資料番号で示す。建物台帳は「建」、家屋届は「届」とする。例えば、建 3は表1の建物台帳の 3 番目「明治廿七年一月改正建物台帳 長者町 西小磯 高麗 他府県他郡他市」を示し、届1は表中、家屋届の1番目「明治二拾九年四月八日起家屋願届書類」を示す。

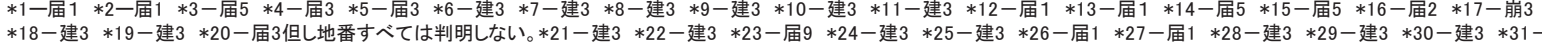

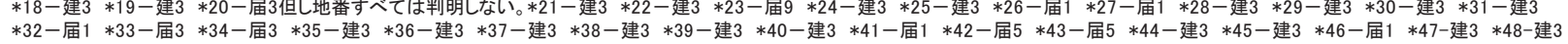




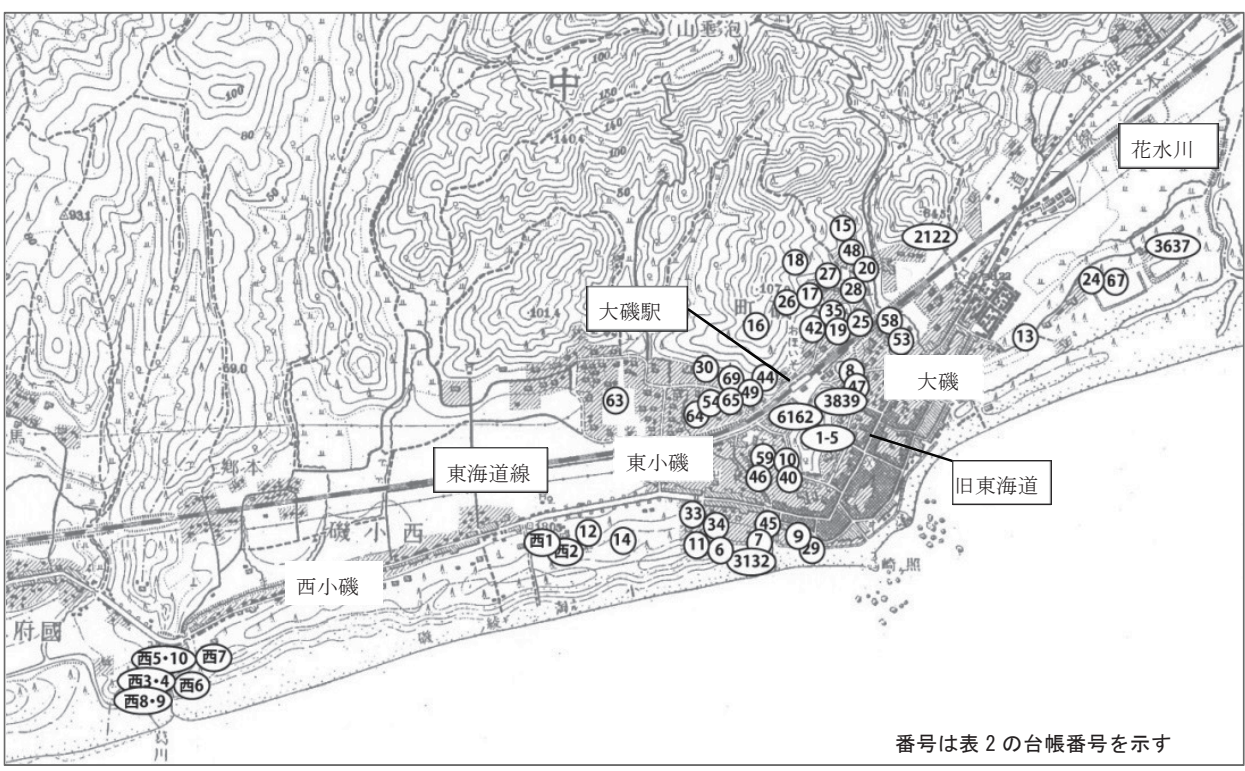

図 530 年別荘等家屋台帳記載別荘の立地 (地図は国土地理院 2 万 5 千分の 1 地形図〈大磯〉大正 10 年測量を使用)

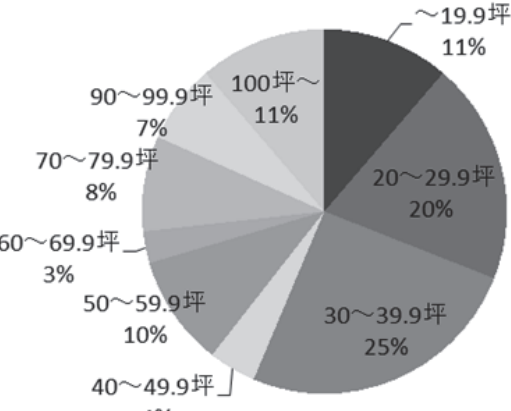

$4 \%$
助の台帳は 5 件、その他三島彌太郎、浅野総一郎など 11 名の家主 の台帳は 2 件にわたって記載される。

91 件には別荘以外も含まれる可能性が高いことから、大磯に所在 する別荘について記載する明治 24(1891)年発行の『相陽大磯一覧之 図』12)、明治 27(1894)年 7 月 31 日発行、同 33(1900)年 7 月改正『神 奈川県大磯明細全図』13)、明治 40(1907)年発行の『大磯誌』14)いず れかに別荘として記載されていることが確認できた 71 件を対象に、 「30 年別荘等家屋台帳」の事項記載欄を簡略化し所在地別に整理し た(表 2) 15)。

以下詳細に特徵を明らかにする。

\section{3-1. 立地および敷地規模}

大磯は北側に高麗山や泡垂山などの丘陵を背負い、南側は相模湾 に開く地形であり、旧東海道は丘陵地と平坦地のいわば境界に位置 する。明治 21(1888)年印刷の「相陽大磯駅全図」16) は鉄道駅設置 直後の大磯の様相を描くが、旧東海道沿いおよび海水浴場付近には 建物が密集するものの、他にはわずかに人家が描かれるのみで、丘 陵や田畑などが広がるのどかな田園風景が描かれる。すなわち、旧 東海道沿いなど一部の敷地を除けば、別荘を建設できる場所は大磯 町全域に広がっていたといえる。

「30 年別荘等家屋台帳」には地番記載のない台帳もあるため、他の 資料から可能な限り地番を特定し、表 2 にイタリック体で追記しこ れを含め別荘の立地を地図にプロットした（図 5)。別荘は風光明媚 な海浜や景観に優れた山裾に多く立地すると考えがちだが、大磯の 場合、かつて大磯宿だった町中心部にも多くの別荘が立地している ことがわかる。大磯駅前には岩崎家の広大な別荘が立地するのを始 め、駅に近接する北側山裾、旧東海道大磯宿の町並みから一筋奥の 敷地にも立地することが確認できる。また、中心部から離れた東小 磯・西小磯には、旧東海道と海岸に挟まれた好立地に、陸奥宗光、 大隈重信、鍋島直大、伊藤博文 ${ }^{17)}$ などの大規模別荘が立地し、さら に町の西端、西小磯字切通にはJ .コンドル長女前波はるや吉田茂・ 上郎幸八、調所廣丈などの別荘が点在する。大磯町の東部、花水川
寄りには、後藤象二郎（後に井上竹次郎）の別荘が立地するなど、 東海道線南側に幅広く別荘が立地する。

「30 年別荘等家屋台帳」に掲載される別荘のうち、敷地規模が記 載されるのは 33 件のみであるため、「27 年別荘等建物台帳」など他 史料から敷地規模を可能な限り明らかにし表 2 にイタリック体で追 記した。大磯駅前の岩崎家別荘は正確な敷地規模を詳らかにしない が、32000 坪とする資料もあり 18 )、大磯で最大級の別荘だった。伊 藤博文別荘 1649 坪、三井高保別荘 1200 坪など敷地規模が 1000 坪 を超える別荘がある一方、稲葉順通別荘 76 坪、三澤元衛別荘 66 坪 など 100 坪以下の敷地規模の別荘もある。敷地規模 100 坪以下の別 荘は神明町、町屋、大門など町中心部に位置する傾向はあるが、立 地と敷地規模とに明確な関係は見いだせない。

\section{3-2. 主屋規模}

台帳筆頭に、「壱号」として記される建物は最も規模が大きく主屋 と考えられる。先に述べたように建物面積は主体部分とそれ以外の 玄関、内縁、2 階など部位別に分割して記載される。例えば、岩崎 彌之助 1 件目台帳の 1 号建物は、99.52 坪の主体部分と 2 階 39.71 坪、玄関 2.64 坪、廊下 4.72 坪、浴室 19.52 坪、内庇縁厠 32.7 坪、 釜場居宅 3.15 坪、同 2 階 3.15 坪からなる。そこで、これらの面積 を合計し主屋延面積とした。

主屋規模をみると、多くの別荘が 100 坪以下であるのに比して、 岩崎彌之助別荘 205.11 坪、鍋島直大別荘 205.23 坪、三井高保別荘 204.57 坪と 200 坪を超える別荘もある。

主屋規模の傾向を明らかにするため 10 坪ごとに区切り分布を見 ると、30 坪から 39.9 坪の主屋規模を持つ建物が最も多い（図 6)。 先に述べたように、同一人物所有家屋であっても地番等が異なる場 合等別台帳に 2 件目として記載されるが、20 坪に満たない建物の多 くは 2 件目として記載される建物であり、台帳上は独立した物件で あっても、一体となった屋敷地内の付属家的な建物である可能性が 高い。

従来、明治期の大磯の別荘は、岩崎家別荘や伊藤博文別荘等、規 
模の大きい別荘建築に代表されると考えられてきたが、「30 年別荘 等家屋台帳」で確認寸る限り、100 坪を超えるような規模の大きい 別荘のみでなかったことがわかる。

\section{3-3. 屋敷構成}

台帳用紙にはあらかじめ 1 号から 12 号まで建物記載欄が印刷さ れており、規模 5 合の則など小規模な建物もすべて記載される。「家 屋図」にはその配置が示され、道路と敷地境界を明記するものもあ ることから、当該敷地内にあった建物の全体が判明する。

主屋以外に設けられる建物としては「居宅」「物置」「厠」「浴室」 などがあり、主屋としての「居宅」以外に「居宅」を置く別荘は 31 件確認できる。主屋以外の居宅規模は高島鞆之助別荘のように主屋 とほぼ同規模だったり、伊藤博文別荘のように 54.5 坪の居宅を置く 場合もあるものの、全体としては 20 坪以下であることが多く、配 置が判明する事例では道路近くに配置されているものもあることか ら、門番や管理人用住宅に該当すると考えられる。台町の小笠原長 幹別荘は 324 坪の敷地内に 71.6 坪の主屋と居宅 2 棟茶室 1 棟物置 1 棟則 1 棟が配置される。居宅の内 6.5 坪の 1 棟は道路脇に配置され ており、管理人用住宅であった可能性が高い（図 7)。

5 件に分割して台帳が作成された岩崎家別荘の場合、合計すると 16 棟の建物が所在したことになり、写真暗室や西洋料理場など特色 ある付属屋が確認できる。

このほか、浴室に着目すると、吉田茂・上郎幸八所有建物は 8.75 坪の「居宅浴室」一棟をもつ。こうした浴室を別棟にする配置は小 林八郎の 7.08 坪の浴室など数例確認できる。

また、「西洋造居宅」すなわち洋館を持つのは伊藤博文（図 8）と 吉田茂のみであり、他にはない。伊藤の場合「30 年別荘等家屋台帳」 に先行する「 27 年別荘等建物台帳」には「西洋造居宅」の記載はな く、その後、明治 29(1896) 年に一旦和館を建設した 19 ) 後、「西洋造 居宅」寸なわち洋館を建設した可能性も考えられる。伊藤は明治 29(1896)年から大磯邸を本邸としており 20)、本邸としての機能には 洋館が不可欠であったことから設置されたと考えることもできる。

また、岩崎久彌、小笠原長幹、大郎重信、鍋島直大は、明治期に 本邸内に和館とともに洋館を設けたことが知られる ${ }^{21)}$ 。一方、「30 年別荘等家屋台帳」から判明する彼らの大磯の別荘は和館のみで構 成され、建物の構成からも別荘が本邸と性格を異にする存在だった ことが伺える ${ }^{22)}$ 。

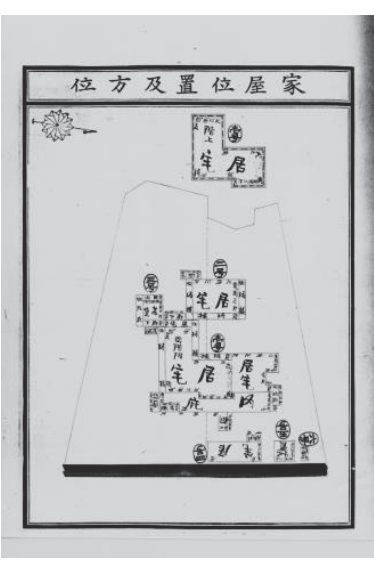

図 7 小笠原長幹別荘「家屋図」

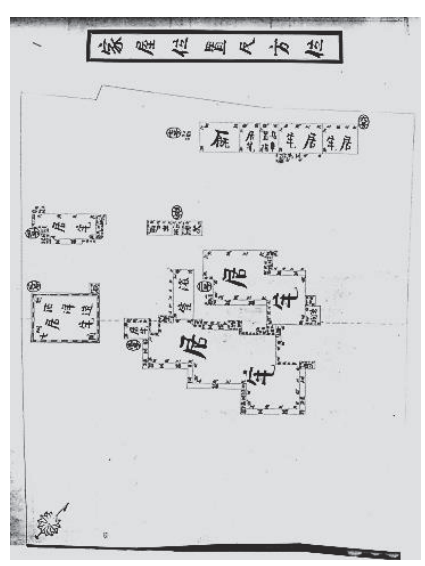

図 8 伊藤博文別荘「家屋図」

\section{3-4. 構造形式（屋根 ·階数）}

主屋屋根は瓦莫とするものが半数を占め、次いで草莫、板莫とな る。草莫の別荘の中には主屋規模の大きい別荘もあり、岩崎家の 205.11 坪及び 164.14 坪の主屋はともに草葺であり、伊藤博文別荘 (図 9)23)や三井高保別荘も草莫である。一方主屋規模の大きい別荘で も、徳川義禮別荘、鍋島直大別荘は瓦莫であり、さらに、島津忠亮、 稲葉順通、小笠原長幹など旧藩主の別荘の場合、屋根仕上げは総じ て瓦莫で草莫の別荘は確認できない。屋根仕上げだけで判断はでき ないが、別荘建築においても格の表現が重視された可能性がある。

明治期上流階級の数寄者たちに草莫の田舎家への志向があったこ とが知られるが、大磯においては明治 30 年代初頭に維新に功績の あった政治家や実業家などによって草莫の田舎家が別荘として建て られていた。数寄者たちの田舎家と同列に論じることはできないも のの、田舎家への憧憬を具現化したものであることは間違いなく、 同時期の他の別荘地における別荘建築の様相を知る手がかりになり 得るものである ${ }^{24)}$

また、屋根仕上げにかかわらず、2 階建の別荘が全体の約 3 割確 認できる。総 2 階の別荘はなく、いずれも 1 階床面積の方が大きい。 2 階建とする場合、 2 階に配置される居室は図 12 酒井忠道別荘にみ るように床棚を備えた続き間であることが多い。

図 10 に示した浅野総一郎別荘外観写真は、明治 26 年(1893)年撮 影とされ、大磯初期別荘建築の様相を伝える貴重な写真である。中 心部から離れた山裾に立地する平屋建瓦莫 66 坪の別荘で、図 2 及

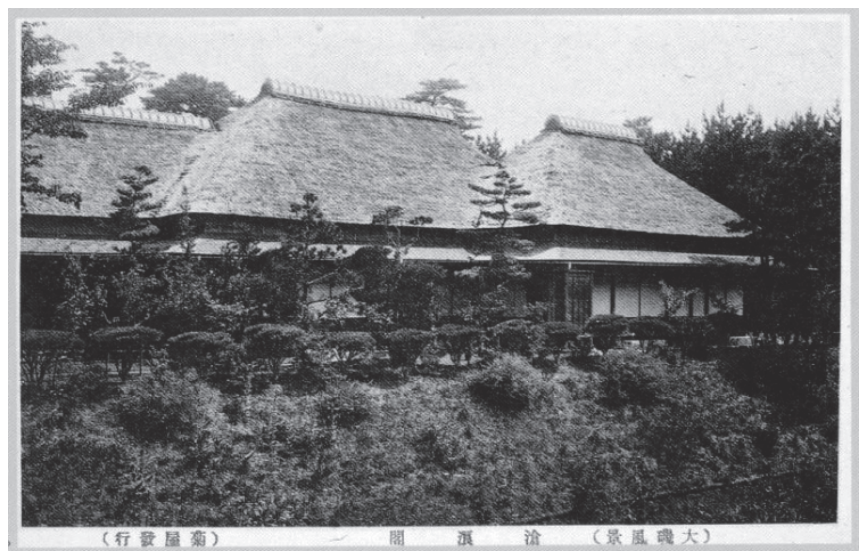

図 9 伊藤博文別荘外観

（横浜開港資料館:百年前の横浜・神奈川，1999，有隣堂 より）

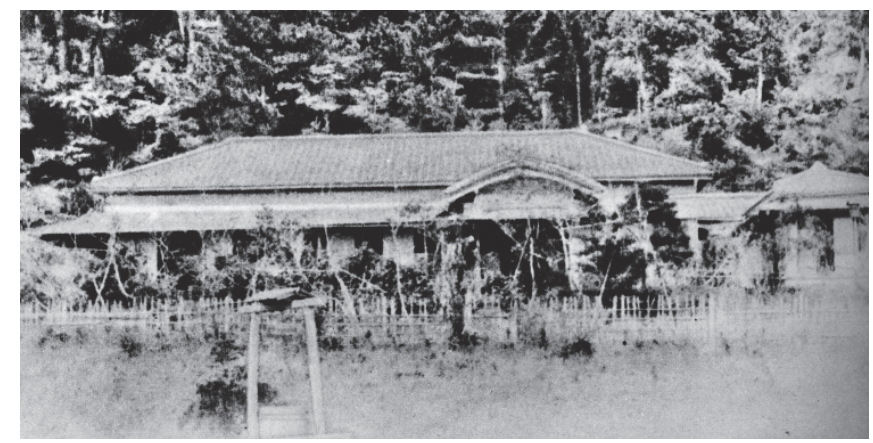

図 10 浅野総一郎別荘外観

(渋沢敬三編: 瞬間の累積渋沢篤二 明治後期撮影写真, 1963 より) 
び図 3 の間取図とも良く合致する。母屋部分を瓦屋根とし、深い板 庇を設けるなど、大磯における初期別荘の様子を知ることができる。

\section{3-5. 平面構成}

$「 30$ 年別荘等家屋台帳」の「家屋図」は玄関、浴室、厠、内縁、 外縁などについては位置や規模を記載するものの、その他について は建物の形状を示すにとどまり、詳細な平面構成は判明しない。

一方、「30 年別荘等家屋台帳」所載の別荘中、「家屋届」や「37 年取崩台帳」から、詳細な平面構成が判明するものがある。

東小磯字小淘綾に立地した延床面積 29.38 坪の黒川彦兵衛別荘に ついては、「大正四年三月調查家屋取崩綴」に簡略な平面図が掲載さ れており、8 盢 2 室の続き間と 6 盢 1 室からなる別荘で、周囲に縁 を巡らせ浴室を庭に突出させた構成に特色を持つ（図 11）。

䇥田に位置する酒井忠道の別荘は建物規模 58.67 坪の別荘で、明 治 30(1897)年 3 月 29 日付で提出された「家屋新築届」25)平面図は、 「家屋図」と良く合致する。1 階に居室 5 室、2 階に居室 2 室を置 き、玄関から最も奥に床棚付の続き間を置き、2 階にも同じく床棚 付の続き間を設け、いずれも周囲に縁を回し開放的な造りとする。 酒井忠道別荘は大磯駅北側の高台に立地しており、3 方に縁を巡ら せた 2 階は、開放的で眺望に優れた居室だったことがわかる(図 12)。

このほか、台帳記載の大隈重信別荘、鍋島直大別荘、陸奥宗光別 荘については、東京都立中央図書館木子文庫に図面 26)があり様相が 判明する。いずれも「家屋図」と良く合致し、大規模別荘の平面構 成を知ることができる。鍋島直大別荘は中庭を囲み居室が配置され る構成で、南面に床棚付の座敷を複数置き、南西角部分は 2 階建と し 2 階にも続き間座敷を置く。北側には台所をはじめ裏方の居室を 並べる。西側には中坪に面して、前室を含めそれぞれ 13.5 睤と 9 畳の広さをもつ浴室を 2 力所置き、浴室の大きさが突出する(図 13)。

他の別荘についても浴室規模 27)を見ると、岩崎弥之助別荘 19.52 坪、三井高保別荘 17.75 坪、伊藤博文別荘 10 坪などであり、また、 黒川別荘や酒井別荘など中小規模の別荘でも浴室は規模が大きく、 突出させるような配置が見られる。先にもみた別棟に配置する事例 を含め、大磯の別荘においては浴室が特別な意味を有していたこと がわかる 28)

また、間取りが判明する別荘は総じて続き間を中心に居室が連続 し、外周に縁をまわす開放的な構成であったことも指摘できる。

\section{4. まとめ 大磯における明治期の別荘建築}

以上大磯町所蔵の家屋関連行政文書の概要を明らかにするととも に、大磯における別荘の黎明期ともいえる明治 30 年代初頭の別荘 建築の様相を「明治 30 年別荘等家屋台帳」などから明らかにした。 以下判明したことを記す。

1.「旧大磯町役場資料」のうち「家屋関連行政文書」は、台帳形式 の文書と届出形式の文書からなり、明治以降の大磯における別荘の 変遷を網羅的に把握可能な文書である。台帳形式の文書 3 種、明治 $29(1896)$ 年から昭和 $15(1940)$ 年まで、 5 年分を除き各年の家屋届 32 冊が所在することが判明した。

2. 明治 30 年代初頭に作成された家屋台帳の中から別荘と特定で きる 71 件の台帳のみを抜粋し、立地、敷地規模、屋敷構成などに ついて検討した。大磯における別荘立地は旧宿場町だった町中心部 から周辺部まで幅広く立地する。敷地規模 1000 坪を超える大規模

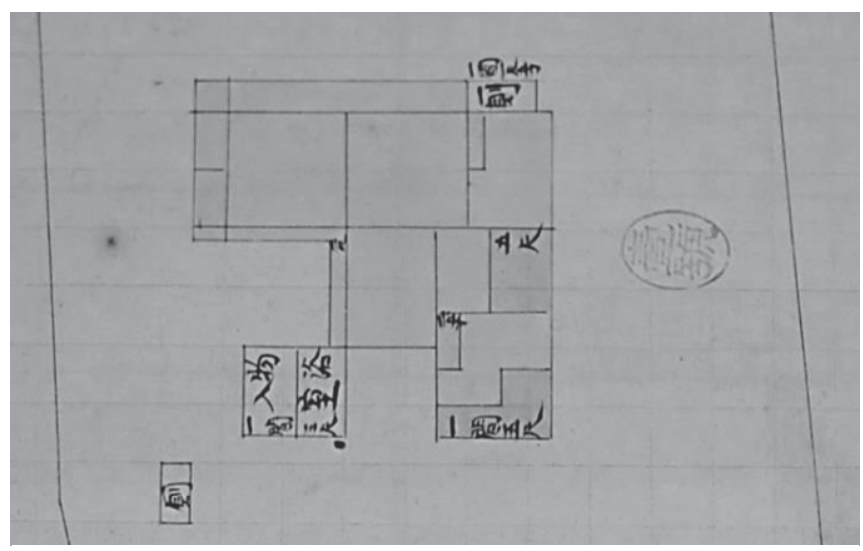

図 11 黒川彦兵衛別荘平面図

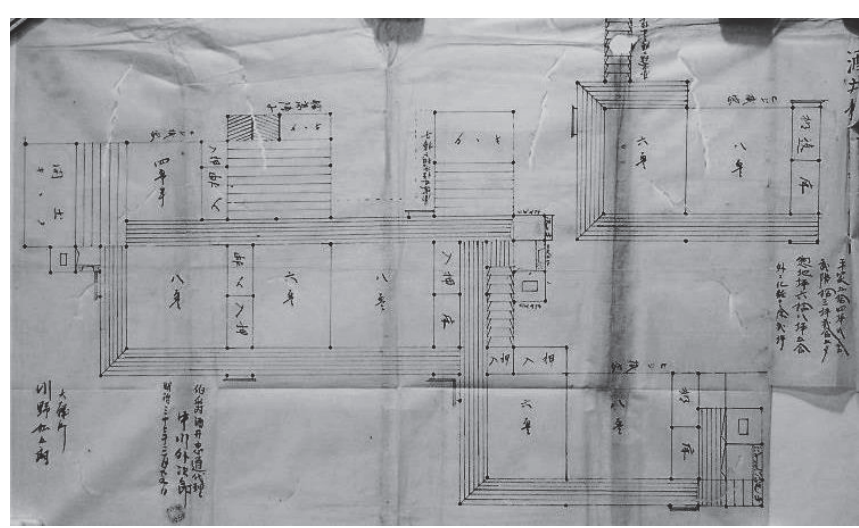

図 12 酒井忠道別荘平面図

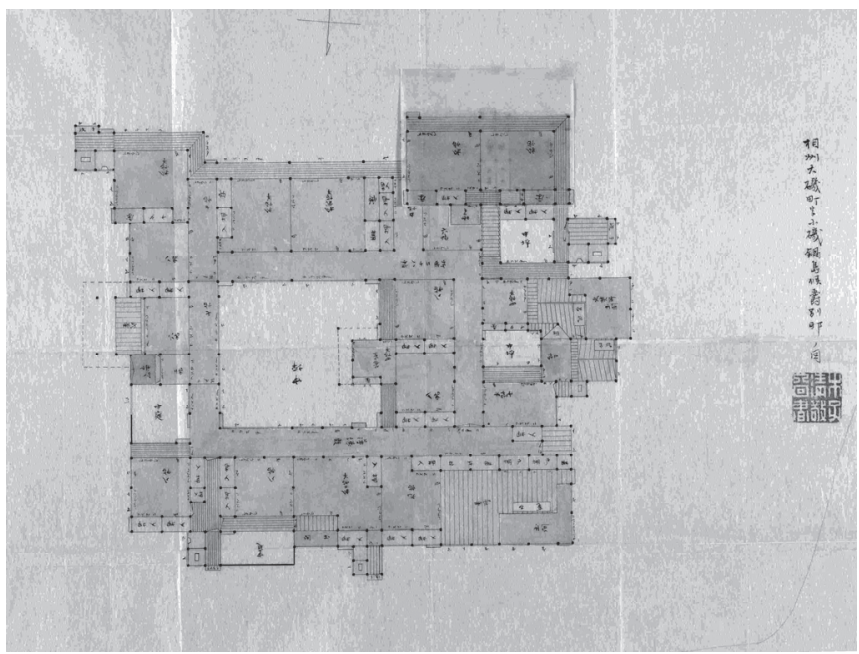

図 13 鍋島直大別荘平面図 (東京都立中央図書館特別文庫蔵 但し部分)

な別荘もあるものの 100 坪以下の別荘も存在した。屋敷内には複数 の建物を設けることが多く、管理人住宅の存在も確認できる。また、 すでに指摘されているような主屋規模 100 坪を超える規模の大きい 別荘も確認できる一方、 20 坪〜 40 坪程度の別荘も多く所在してい たことが判明した。

3. 主屋規模の大小に関わらず屋根を草莫とする別荘があり、田舎 家風の別荘建築への嗜好を指摘できる。草葺の別荘を設けるのは明 
治維新で功績のあった政治家や実業家であり、旧藩主別荘は総て瓦 莫だった。

伊藤博文及び吉田茂所有建物を除きほとんどの別荘が和館のみか らなる構成であり、屋根仕上げにかかわらず 2 階を設ける別荘も確 認できるなど、その様相は極めて多様だった。

4. 主屋は続き間の座敷を基本とし、周囲に縁を巡らす開放的な構 成をもつ。主屋内もしくは別棟に規模の大きい浴室を設置する別荘 があり、その配置も主屋から突出させるなど特色ある配置だった。 大磯の別荘建築における浴室の重要性を示唆するものと考えられ注 目される。

大磯における明治 30 年代初頭といえば、海水浴場設置や、鉄道 駅設置からわずか 10 年ほどが経過したのみであり、この時点です でに高名な政財界人や華族の別荘が多数設けられていたことは、大 磯が別荘地として爆発的な速度で発展していったことを物語る。

ところで、『大磯の寸まい』は大磯の別荘建築を 3 期に分け、そ の特徵を述べている。明治中期から後期を第 I 期とし、大規模な別 荘建築が存在することや、周辺部に多く立地すること、敷地の広い 景観の良い場所に立地すること、華族など明治維新に貢献した財閥 や高級官僚が多く別荘を設置し、和洋館を併置した大邸宅型の別荘 建築が存在することなどを指摘している。

$「 30$ 年別荘等家屋台帳」の検討から判明するのは、『大磯のすま い』が指摘したような特色をもつ別荘のみではなく、きわめて多様 な別荘建築が存在していた様相である。多様な別荘建築の存在は、 本邸がいわば公的生活の器として社会性をもつことにより社会の規 範をより強く反映するのに比して、明治 30 年代初頭の別荘は私的 性格の強い存在であったことを物語る。立地や構造形式の多様性は、 自らの好みを反映した結果と考えられる。また、大磯が湘南の他の 別荘地と異なり、既存の宿場町を内包しながら発展した別荘地であ り、保養地としての側面のみでなくある種の都市性をあわせもって いたこととも関連するかもしれない。地域や時期ごとのより詳細な 検討が必要であると考えられる。

『大磯の住まい』刊行後既に 20 年が過ぎた。この 20 年間に大磯 の優れた別荘建築の多くが失われた。現存する貴重な別荘建築を継 承する上で、その価值をさらに詳細に明らかにすることは重要であ り、「旧大磯町役場資料」は、大磯町における別荘建築の様相を明ら かにする上で貴重な資料となりうるものである。

本稿は 2009 年度 2011 年度科学研究費補助金基盤研究(C)によ る研究成果の一部である。研究に際し大磯町立図書館古畑哲也氏, 同原田睦子氏にお世話になった。記して感謝いたします。

注

注 1) 大磯町教育委員会 : 大磯町文化財調査報告書第 37 集 大磯の寸まい(1) 1992 「磯の別荘建築について」と題する総論と、現存 31 件を含む 34 件の別荘建築についての調查報告、主要別荘居住者一覽表、大磯別荘建 築調査リストからなる。

注 2) 大磯町：大磯町史 7 通史編 近現代 2008、同書では『大磯の住ま い(1)』の記述を引用し、明治の中期から後期にかけて旧公家、維新で功績 のあった高級官僚、財閥が別荘を構え、こうした人々は「大磯の中心から それた西小磯や高麗東小磯を好み浜辺近くや高麗山の麓、小高い丘の眺望 の良い場所に広い屋敷地を確保し、大邸宅を構えることが多かった。洋館
部と和館部を別にした造りや、鍋島直大や三井高棟邸をはじめとして母屋 が 100 坪を超える邸宅も見られた」としている。

注 3) 大磯町郷土資料館：『なつかしの風景 II 家と町並み 大磯町郷土資料 館企画展図録』1992 同書は古写真からかつての別荘の様相を示した企 画展の図録であり、その中で洋館が別荘として登場するのは関東大震苂後 のことであると指摘し、それ以前は『滄浪閣』や『岩崎邸』に見られる平 屋茅莫か 2 階建て瓦莫の日本家屋であったこと、茶室などの付属施設を設 けることが多かったことを指摘し、贅を尽くす象徴としての別荘は大正期 以降のことでありそれ以前は簡素なたたずまいであったと指摘している。

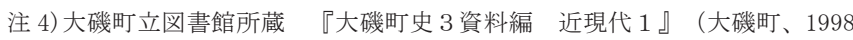
年）によれば、当該文書は旧大磯町役場で役場事務に使用されていた公文 書であり、各部課の関連事項ごとに一括して綴じ込まれており、簿冊形式 をとる。

注 5）筆者はすでに当該資料を用い(1)「大磯における明治期の別荘建築『明 治二七年一月改正建物台帳』などによる検討」（日本建築学会大会学術講 演梗概集 2007 年)、(2)「明治期家屋台帳による大磯の初期別荘建築に関す る検討」（日本建築学会大会学術講演梗概集 2008 年）(3)「大磯町家屋関連 行政文書による別荘建築の履歴」（2010 年度日本建築学会関東支部研究発 表会研究報告集 II）(4)「明治大正期における大磯町西小磯の別荘建築」（日 本建築学会大会学術講演梗概集 2011 年) (5)「明治大正期における大磯町東 小磯の別荘建築」(日本建築学会大会学術講演梗概集 2012 年) を報告した。

注 6) 岩崎弥之助 2 件目台帳備考欄に 33 年 3 月 2 日届出の名義変更が記載さ れており、これ以前に作成されたことがわかる。また、「明治二十九年四 月起建物願届書類」には明治 30 年 5 月 3 日付け建物取得届出をした大隈重 信の届けが記載されていること、「明治三十一年一月起建物二関スル書類」 には明治 31 年 3 月 21 日付けで「建物届」を提出した原敬 (河田 罯 : 大磯 誌 1907 に別荘所有者として氏名がある)は記載されていないことなどか ら、明治 30 年後半に作成された可能性が高い。

注 7) 備考欄記載の日付のうち、大磯町 1116 番に建つ板葺居宅の売買の日付 として明治 $37(1904)$ 年 11 月 5 日が記載されているためこれ以前に作成さ れたと考えられる。

注 8) 前波クメはジョサイア・コンドルの妻。ハルは同長女。

注 9) 明治 $36(1903)$ 年 2 月から $37(1904)$ 年 3 月、大正 5 (1916) 年 4 月から大 正 $6(1917)$ 年 3 月、昭和 $3(1928)$ 年 5 月から昭和 4 (1929) 年 1 月、昭和 8(1933) 年 4 月から昭和 $9(1934)$ 年 3 月、昭和 $11(1936)$ 年 4 月から 12 (1937) 年 3 月 の届出は確認できない。

これらの届出は、家屋の課税根拠とするために義務付けられていたものと 考えられ、大磯町「明治三十七年度県税戸数割賦課義案」第 4 条には「家 屋を新築したる者は落成の時その種類坪数及び場所を詳述し縮図を添え五 日以内に届出つベしその敷地他人の所有に係わるときは地主の連署を要 するものとす」とし、また、第 5 条には「家屋の種類を変更し又は坪数を 増減し、もしくは焼失廃棄しもしくは売買譲与を為したるときは五日以内 に届出」とあることから、家屋に関わる多様な届出が義務づけられていた ことがわかる

注 10) 明治 $43(1910)$ 年 1 月 13 日から同年 12 月 27 日までの届けを綴った表題 のない届出文書による。

注 11)「27 年別荘等家屋台帳」掲載別荘については、すでに注 5(1)で検討し 報告した。

注 12) 三宅藤兵衛 : 相陽大磯一覧之図 1891 年 6 月印刷 当該地図上には以 下の別荘が記されている。

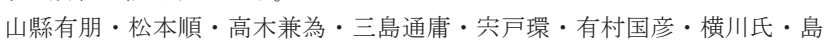
津家荘・野村氏荘・村田氏荘・粟野氏荘・森村市太郎・吉田利助氏荘・浅

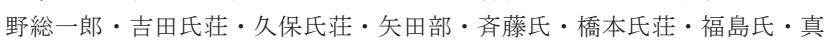
鶴氏・調所氏 - 外国人荘・柴山氏荘・本田氏荘 - 周布氏荘 - 外人別荘（台 町）・樺山氏荘・山村氏荘・吉田氏荘 - 河野氏別荘 - 宮原氏荘 - 小笠原氏 荘・宾戸氏荘・永松氏荘・岩崎氏荘・若宮氏荘・原氏荘・諫早氏荘・今村 氏邸・ 小山氏邸・佐藤氏荘 $\cdot$ 佐羽氏荘・後藤別荘・ 一森氏所有地 $\cdot$ 三井邸 地・石井氏地 - 市川氏地 - 池田家所有地 - 多田氏地 - 清田氏所有地 - 佐々 木氏地・吉田氏地 - 左右田氏ノ地 - 塩谷氏ノ地・新島氏之地・町田氏之地 · 注 13) 三宅政之：神奈川県大磯明細全図 1894 年 7 月 31 日発行、1900 年 7 月改正 当該地図には以下の別荘が記されている。

山縣伯荘 - 橋本別邸 $\cdot$ 上呂氏荘 $\cdot$ 吉田氏荘 $\cdot$ 伊藤別荘 $\cdot$ 三井家荘 $\cdot$ 調所氏 荘・コンデル氏荘・桜井氏荘・清水別邸・飯田別邸・西園寺候荘・伊藤候 邸 - 鍋島候邸 $\cdot$ 大隈伯荘 $\cdot$ 古川氏 $\cdot$ 徳川氏荘 $\cdot$ 本多氏荘 $\cdot$ 隈本氏荘 $\cdot$ 平井 氏荘・村田氏荘・黒川氏荘・田中氏荘・山内候荘・濱氏荘・薄井氏荘・山 内氏荘・ 小林八郎荘 - 松平家荘 - 小笠原氏荘 - 藤田氏荘 - 岩崎氏荘・樺山 


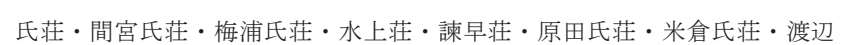

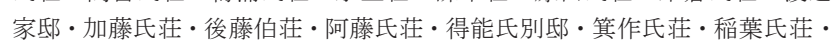
西氏荘・有村氏荘・高木氏荘・森村氏荘・有村氏荘・浅野氏荘・酒井家・

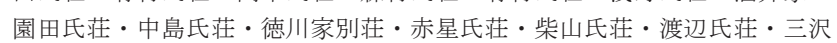
氏荘 - 藤田氏荘 - 張氏荘 - 松本氏荘 $\cdot$ 杉谷氏荘 - 西村氏荘 $\cdot$ 谷口氏荘 $\cdot$ 依 田別邸・田中氏荘 · 原六郎氏地 $\cdot$ 羽白氏荘 - 三嶋氏荘

注 14）河田 罵: 大磯誌 1907、108 件の別荘を字別に整理して掲載する。記 載別荘は以下の通りである。

北本町：島津忠亮伯 - 梅浦精一 - 木下健平 - 渋谷喜助 - 早川サク・秋山啓 蔵・高松純重・平山幸吉・宮島善次郎 - 原田熊雄・村田常次郎 南本町 : 岩崎弥之助・清水清兵衛 - 間宮作次郎 南下町 : 原敬・杉原栄三郎・森田 銀次郎・ 中澤紀・ 小菅伊三郎・千葉鑛蔵 茶屋町 : 樺山資紀伯・小泉繁之 助・ 千葉松兵衛 - 細田安兵衛 - 米倉長一郎 - 辻市兵衛 - 高田慎蔵 神明町 : 阿藤重兵衛 - 酒井忠道伯 - 高島鞆之助子 - 三島弥太郎子 - 稲葉順道子 - 奥 田直弘子・高木兼宽 - 箕作俊夫 - 岡田実徳 - 西増子 - 得能通要 - 有村国彦 森村市太郎・浅野総一郎 山王町: 中島熊吉・藤本イチ 台町 : 山縣有朋 徳川義怒 - 山内豊景 - 小笠原長幹・村田経芳・田中茂・江互・深井クラ ・

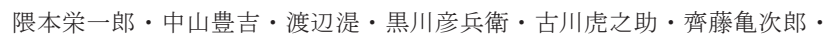
原六郎・佐々木勇之助・薄井佳久 · 安田光太郎 - 林安五郎 - 岡田守三 - 山 内堤雲 $\cdot$ 松平豊子 - 小林又七 東小磯 : 真田幸正 $\cdot$ 松本順 $\cdot$ 加藤高明 $\cdot$ 三 井養之助・柴山矢八 ・ 赤星鉄馬 ·西村勝蔵・ 三澤元衛 $\cdot$ 渡邊治右衛門・片 岡七郎・西彦兵衛 ・榎本栄蔵・高松龍・藤田ギン・田中長兵衛・福島福太 郎・竹村キョウ・二神寬次 · 張拡蔵・依田松呂 $\cdot$ 中村茂八 · 池谷昌吉 $\cdot$ 河

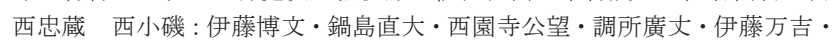
清水満之助・田倉代小洲・吉田茂・上郎幸二・柿沼卯兵衛・メンデルソン・ ビゴット・コンデル 長者林 : 吉川重吉・渡邊千秋・岩井音五郎・根津嘉 一郎・村井吉兵衛 高麗 : 徳川頼倫

注 15) 91 件中、上記注 $12 \sim 14$ に別荘としての記載が確認できなかったのは以 下の 20 件である。

渡辺文、沖守固 (2 件)、川田龍吉、原田よし、石井健吾、遠上均一、六角 謙吉、男全三郎 (2 件) 、吉田茂 (2 件)、依田稔、左右田金作、熊坂鎌太郎、 大谷光尊、土方八百松、佐野市郎、高木新助、善野夕衫

このうち沖守固については、明治 21（1888）年 8 月 16 日付毎日新聞に大 磯に別荘を建築中との記事があり、別荘を有していた可能性が高いが注 12 〜14には確認できなかった。吉田茂所有の 2 件は、北下町に所在し居宅と 大弓場からなる台帳であり、注 12 には「吉田氏荘」「吉田氏之地」とある ものの、注 $13 、 14$ には同所に記載がないためここでは別荘と判断しなかっ た。左右田金作については注 12 に記載があるものの位置が異なることから 未確認とし、高木新助についても注 13 に記載があるものの位置が異なるこ とから未確認とした。

注 16) 三宅政之：相陽大磯駅全図 1888 年印刷

注 17) 滄浪閣として知られる伊藤博文別荘は「明治二拾九年四月八日起 建 物願届書類」によれば明治 29（1898）年 10 月 31 日付けで「家屋建築届」 が提出されている。注 2 『大磯町史』によれば、同年伊藤は大磯に住民票 を移し、30 年には本籍も大磯に移している。従って、別荘とするのは正確 ではないものの、ここでは別荘として扱うこととする。

注 18）大磯町教育委員会 : 大磯町文化財調査報告書第 37 集 大磯のすまい (1) 1992

注 19）「明治二拾九年四月八日起 建物願届書類」によれば伊藤博文は明治 $29(1896)$ 年 10 月 31 日に茅莫平家建家屋 172.25 坪の建築を届け出ている。 その後、西洋館の建築については届を確認できない。

注 20）大磯町：大磯町史 7 通史編 近現代 2008 工学会 1927

注 21) 岩崎久彌が明治 29 (1896) 年建設した茅町本邸は、ジョサイア・コンド ル設計の洋館と和館（和館竣工は明治 30 年）から成る邸宅としてよく知ら れている (国指定重要文化財)。また、鍋島邸、小笠原邸、渡辺邸について は『明治工業史』（工学会; 1927 年）に洋館建設の記載があり、大隈重信 は、明治 35 (1902) 年に保岡勝也設計による洋館を日本館に連続して建てた ことが「建築雑誌」明治 35 (1902) 年 11 月号建築雑誌に報告されている。

注 22）明治期における大磯の洋風別荘建築として、ジョサイア・コンドル設 計の赤星鉄馬別荘洋館がよく知られる。赤星家の大磯における別荘の履歴 をみると、鉄馬の父赤星弥之助は明治 31 (1898) 年 10 月に東小磯字海辺 287 に別荘の建築を届け出ている(「明治三十一年一月起建物二関スル書類)。 届出に付された「大磯宿字小磯松林内之御別荘絵図」と題する図からこの 別荘は和館のみからなる 2 階建建物であることが判明する。また、赤星鉄 馬は明治 $40(1907)$ 年 6 月に東小磯に新たに「石造西洋館」を含む別荘の新 築を届出ている(「明治三十七年度起建物ニ関スル書類」)。この時建設さ
れたのが先のジョサイア・コンドル設計の別荘だったと考えられる。洋館 のみでなく和館も併設する別荘だったことは『大磯のすまい』にも指摘さ れている。

注 23) 伊藤博文は現在の横浜市金沢区野島にも明治 31 （1898）年に茅莫の別 荘を設けている(横浜市指定文化財)。金沢別荘は大きく 3 棟からなる建物 で、開放的な居室棟、規模の大きい浴室を突き出して配置する構成は大磯 の初期別荘建築と共通している。

注 24）明治期における数寄者たちによる田舎家については、土屋和男による 「近代数寄者の茶会記録に見られる「田舎家」に関寸る記述」（日本建築学 会計画系論文報告集 2013 年 5 月）などの論考がある。別荘建築における田 舎家風意匠については、すでに筆者（共著者 加藤仁美、小沢朝江）が「近 代における皇族別荘の立地・沿革及び建築・使い方に関する研究」（住宅総 合研究財団研究年報N No.27 2000 ) の中で皇族別荘における志向を指摘し、 公家別荘の伝統を引くものである可能性を指摘した。

注 25) 大磯町所蔵「明治二拾九年四月八日起＼cjkstart建物願届書類」

注 26) 東京都立中央図書館木子文庫 所蔵番号 木 067-010-001 004 相州 大磯大隈伯陸奥伯鍋島伯各別邸之図

注 27）「30 年別荘等家屋台帳」では、部位ごとに規模を記入しており、浴室 規模が判明する。

注 28) 木子文庫所蔵の陸奥宗光別荘平面では、主座敷に付属して浴室が置か れることが確認できる。また、大隈重信は明治 30 (1897) 年に別荘を購入後、 10 坪ほどの浴室を増築しており、(拙稿「旧大隈重信大磯別荘の履歴」2015 年度日本建築学会大会梗概集 F) 、上記の事例からも海浜別荘における浴室 の重要性を知ることができる。 


\section{CONSIDERING THE CONSTRUCTION OF VACATION VILLAS IN OISO THROUGH MEIJI PERIOD HOUSING REGISTRIES}

Research into the construction of vacation villass in modern OISO

Yoshiko MIZUNUMA*

* Prof., Dept. of Human Environment, Kanto Gakuin University, Dr.Eng

Oiso-machi opened an area for bathing beach in 1885 and had a train station built in 1887. These served as opportunities for it to develop into an area for vacation villas. In the pre-war period, not only Oiso but all of Shonan became an area for villas. However, damage from the Great Kanto earthquake of 1923 and post-war development in the Showa Period virtually removed all traces of these Meiji villas. Few clues remain to help us understand more about their construction.

This paper aims to examine these villas trough the "Oiso Town Hall Administrative Documents" and other materials from the turn of the 20th Century, which could be said to be the early period of these villas.

First, this paper examines all of the "Administrative Documents Related to Housing" from the "Oiso Town Hall Administrative Documents." These include three types of registries, as well as housing reports for all but five of the years from 1896 to 1940

Next, details of the construction of these villas were examined through 71 entries in housing registries specified as villas, drawn from among all housing registries created at the turn of the century. Vacation villas were located throughout Oiso from east to west, even in central parts of the city. Though some homes were built on large plots of land, others were on plots less than 330 square meters. Also, in terms of the size of the main building, while there were some large-scale homes, $70 \%$ of the main buildings were small to medium sized at 198 square meters or less.

In many cases, multiple buildings were constructed, such as a home for someone to maintain the property. In addition, there were buildings with thatched roofs regardless of size, which reflects a preference for rural-style homes. The ones who built these thatched roof villas were the politicians and businessmen who contributed to the Meiji Restoration; the villas of former feudal lords were always tile-roofed. Some buildings even had two stories. We can thus conclude that there was a great diversity among the villas constructed.

Most of the villas consisted of Japanese-style buildings. Also, there were cases where large bathhouses and bathtubs were built, which suggests the importance of bathing facilities at these seaside villas. 